\title{
Konferencja naukowa „0 tym się nie mówi - osoby stabostyszące w edukacji, na rynku pracy i w sferze społecznej", Lublin, 8 maja 2015 r.
}

\section{Organizacja: Koło Naukowe Studentów Niesłyszących i Stabostyszących „Surdus Loquens” oraz Centrum Edukacji Niesłyszących i Stabosłyszących Katedra Pedagogiki Specjalnej Katolickiego Uniwersytetu Lubelskiego Jana Pawla II we wspótpracy z Biurem Pełnomocnika Rektora ds. Studentów Niepełnosprawnych}

\section{Dostępność multimediów: napisy na żywo w transmisji online}

\section{Monika Szczygielska}

Dostępni.eu/ Fundacja Widzialni

Napisy na żywo tworzone metodą respeakingu to przełom w dostępności wydarzeń na żywo i transmisji online dla osób z dysfunkcjami słuchu.

Metoda respeakingu polega na przekładzie mowy na tekst z użyciem oprogramowania do rozpoznawania i transkrypcji mowy polskiej. Proces ten jest zależny od respeakera, którego zadaniem jest powtarzanie za mówcą do mikrofonu wypowiedzi, a następnie korekta przetworzonego przez program tekstu. W Polsce metoda stosowana jest przez zespół Dostępni.eu, który pracuje na polskim programie Magic Scribe (Unikkon Integral).

Tą metodą powstają napisy m.in. do programów nadawanych na żywo w BBC, ale nie jest ona stosowana w polskiej telewizji.

Od premiery 7 czerwca 2013 roku napisy na żywo w transmisji online są stale rozwijane. Były realizowane m.in. podczas konferencji w Sejmie RP oraz mszy kanonizacyjnej Jana Pawła II. Z powodzeniem testowana była możliwość dostarczania napisów do transmisji na odległość oraz przekładu z języków obcych.

Jakość napisów na żywo badana jest za pomocą programu NER STAR, łączącego automatyczną analizę statystyczną z badaniem jakościowym z udziałem badacza. Program został opracowany przez zespół naukowców z Uniwersytetu w Roehampton i od 2013 roku jest stosowany do badania jakości napisów nadawanych na żywo w telewizjach brytyjskich. Dokładność napisów jest obliczana na podstawie modelu NER według następującego wzoru:

$$
\mathrm{NER}=(\mathrm{N}-\mathrm{E}-\mathrm{R}): \mathrm{N} \times 100
$$

$\mathrm{N}$ oznacza całkowitą liczbę słów w próbce $\mathrm{z}$ napisów na żywo, E to liczba błędów edycji, a $\mathrm{R}$ - liczba błędów rozpoznawania. Drobne błędy edycji lub rozpoznawania (których znaczenie jest zrozumiałe) są punktowane od 0,25; standardowe błędy (gdzie błąd jest oczywisty, ale utrudnia lub uniemożliwia on rozumienie) są punktowane 0,5 ; natomiast poważne błędy (jeżeli błąd nie jest oczywisty dla czytelnika, np. $15 \%$ zamiast 50\%) otrzymują 1 punkt.

Badanie jakości napisów na żywo przeprowadzono w oparciu o zapis konferencji w Sejmie RP z 17 marca 2015 r. Poniższy wykres prezentuje jakość napisów przed modyfikacją i po niej w pierwszej i drugiej części konferencji.

Polska: Jakość napisów podczas konferencji 17.03.2015

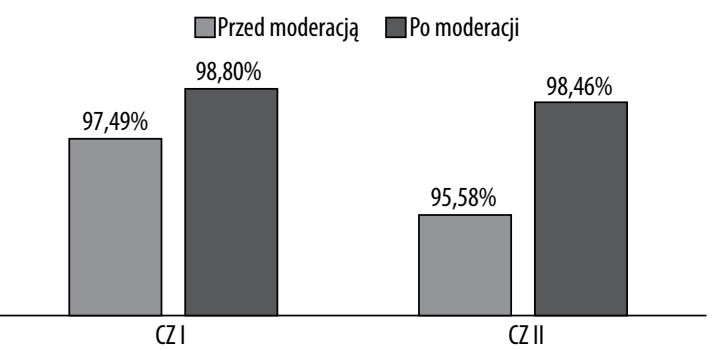

Brytyjscy naukowcy ustalili, że 98\% to wartość progowa, powyżej której jakość napisów może być uważana jako „do przyjęcia" w transmisji telewizyjnej.

Dla porównania przedstawiamy wyniki pierwszego badania jakości przeprowadzonego na zlecenie OFCOM w Wielkiej Brytanii po 10 latach od wprowadzenia obowiązku prawnego emisji $80 \%$ napisów w TV ${ }^{1}$. Średnia jakość napisów dla programów newsowych dla wszystkich nadawców TV wynosi 98,60\%, a dla talk show - 98,15\%.

Realizowane przez Dostępni.eu napisy osiągają jakość napisów, jakie emitowane są w brytyjskich telewizjach. Zespół osiąga to m.in. dzięki stałemu szkoleniu respeakerów,

1. OFCOM, Measuring live subtitling quality: results from the first sampling exercise, 30.04.2014 http://stakeholders.ofcom.org.uk/consultations/ subtitling/sampling-results/. 
jakości programu do rozpoznawania mowy i oprogramowania wspierającego, zachowaniu wysokich standardów pracy, korzystaniu z badań preferencji użytkowników napisów.

Słowa kluczowe: napisy (respeaking) na żywo • dostępność wydarzeń (accessibility) • model NER • symultaniczny przekaz tekstowy

\section{Praktyka studencka w Hamm (Niemcy) - nasze doświadczenia jako osób niesłyszących}

\section{Patrycja Nosowicz i Agnieszka Brylska}

Wydział Studiów Edukacyjnych i Wydział PedagogicznoArtystyczny w Kaliszu, Uniwersytet im. Adama Mickiewicza w Poznaniu

Celem wystąpienia był opis praktyki pedagogicznej w ramach programu Erasmus w Hamm (Niemcy). Studentki przedstawiły doświadczenia zebrane podczas trzymiesięcznego pobytu w niemieckich szkołach, począwszy od szkół masowych po szkoły specjalne.

Autorki omówiły również problemy związane z ich indywidualnymi uszkodzeniami słuchu. Celem było udowodnienie, że osoby niesłyszące lub słabosłyszące mogą brać udział w programie Erasmus.

Praktyki odbywały się w takich placówkach oświatowych, jak: szkoła podstawowa, przedszkole sportowe, szkoła przyszpitalna, szkoły specjalne, szkoła waldorfska i szkoły dla niesłyszących w Munster. Studentki otrzymały pomoc tłumaczeniową w zakresie języka niemieckiego i migowego, dzięki czemu zajęcia pozwoliły uczestniczkom na poszerzenie wiedzy o systemie edukacji w Niemczech, metodach nauczania. Miała również miejsce bezpośrednia interakcja z uczniami, czyli prowadzenie zajęć takich jak plastyka czy nauczanie języka migowego.

Praktyki pozwoliły uczestniczkom rozwinąć się plastycznie, pokazały, jak prowadzić zajęcia $z$ dziećmi i młodzieżą oraz w jaki sposób zachęcić ich do twórczego spędzania czasu wolnego.

Zastosowana metoda obserwacji pozwoliła na dokonanie analizy porównawczej kształcenia w niemieckim systemie edukacyjnym z systemem polskim. Na szczególną uwagę u naszych zachodnich sąsiadów zasługuje różnorodność placówek oświatowych, które są bardzo dobrze wyposażone i dysponują znakomitą kadrą. Należy również wspomnieć o bogactwie udogodnień dla uczniów z różnymi dysfunkcjami.

Dla naszych uczestniczek było to niezwykłe doświadczenie. Po raz pierwszy osoby z wadą słuchu podjęły praktyki w ramach programu Erasmus uczelni UAM, mając nadzieję, że będzie to przełom dający szansę kolejnym osobom na wyjazd i poznanie nowych wyzwań.

Słowa kluczowe: Erasmus • praktyki • Hamm • nie(do)słyszący • język migowy

\section{Jakość wsparcia oferowanego studiującym osobom z wadą słuchu - analiza badań własnych}

\section{Beata Krystkowiak}

Wydział Studiów Edukacyjnych, Zakład Psychologii Dziecka, Uniwersytet im. Adama Mickiewicza w Poznaniu

Wprowadzenie: Badania przeprowadzono na dwóch próbach. Uczestniczyło w nich 25 studentów nie(do)słyszących ze wszystkich wydziałów Uniwersytetu im. Adama Mickiewicza w Poznaniu oraz 50 wykładowców z pięciu wydziałów, na które uczęszcza największa liczba studentów biorących udział w badaniu. Celem było wskazanie, z jakimi problemami borykają się studenci z wadą słuchu oraz na jakie wsparcie mogą liczyć ze strony uczelni i wykładowców.

Materiał i metody: Zastosowano dwa kwestionariusze z pytaniami otwartymi i zamkniętymi. Studentom zadano 49 pytań, a wykładowcom - 39.

Wyniki: Na podstawie kwestionariuszy przeanalizowano odpowiedzi na wszystkie pytania. Do prezentacji wybrano uwagi najciekawsze i najistotniejsze dla przedstawionego tematu - po $10 \mathrm{z}$ każdej próby badawczej.

Wnioski: Wśród wykładowców akademickich przeważała opinia, że studenci nie(do)słyszący to nieliczna grupa w społeczności akademickiej oraz że narażeni są oni na liczne bariery komunikacyjne. Większość z nich nie wie, jaką ofertę wsparcia posiada uczelnia, a prawie połowa ankietowanych nie wiedziała, gdzie ma się udać w celu uzyskania pomocy przeznaczonej dla osób nie(do)słyszacych. Jedynie $32 \%$ wskazało, że brało udział w szkoleniach z zakresu edukacji i komunikacji z osobami nie(do)słyszący$\mathrm{mi}$ a $75 \% \mathrm{z}$ nich wyraziło chęć udziału w takim szkoleniu. Wśród studentów nie(do)słyszących najwięcej ankietowanych wskazało problem $\mathrm{z}$ komunikacją oraz brak materiałów dydaktycznych niezbędnych do zaliczenia kolejnych etapów studiów (brak literatury, notatek własnych). $76 \%$ nie miało problemu $\mathrm{z}$ otrzymaniem pomocy. Pytani o rodzaj wsparcia, jakiego oczekuja ze strony uczelni, najczęściej wskazywali pomoc tłumacza polskiego języka migowego, zadbanie o dobrą akustykę sal, dostępność sprzętu wspomagającego słyszenie i materiałów dydaktycznych oraz pozytywne nastawienie pracowników uniwersytetu. Tylko $8 \%$ studentów brało udział w konsultacjach, które miały na celu zweryfikowanie wprowadzenia nowej oferty pomocy. Na pytanie, czy w ich opinii nauczyciele akademiccy są przygotowani do pracy ze studentami nie(do)słyszącymi, tylko $8 \%$ odpowiedziało, że tak.

Niniejsze badania są ważne ze względu na opinię studentów, dla których przeznaczona jest pomoc. Potrzebna jest weryfikacja wdrożonych rozwiązań, bieżąca analiza i modyfikacja w zależności od potrzeb, a także zmiana podejścia do problematyki studiowania osób z dysfunkcją słuchu. Ważnym elementem byłoby wprowadzenie obowiązkowych szkoleń dla pracowników administracyjnych i dydaktycznych, mających na celu zmianę świadomości dotyczącej osób nie(do)słyszących. 
Słowa kluczowe: nie(do)słyszący studenci • wsparcie • bariery

\section{Nauka języków obcych przez osoby słabosłyszące i niesłyszące}

\section{Katarzyna Moszczyńska}

Instytut Anglistyki, Uniwersytet Warszawski

Języki obce są niezbędne we współczesnym świecie, a ich nieznajomość może prowadzić do wykluczenia społecznego. Jednakże wielu nauczycieli jest przekonanych, że osoba słabosłysząca nie może nauczyć się języka obcego - stąd namawianie uczniów do zwalniania się z drugiego języka.

Badania przeprowadzono metodą ankietową. Oprócz danych demograficznych, analizowano samoocenę poziomu zaawansowania w języku obcym. Do oceny poziomu zaawansowania użyto kwestionariusza CEFR (Common European Framework of Reference), ale usunięto pytania dotyczące rozumienia ze słuchu. Ankiety wypełniło 11 osób, w tym autorka (osoba słabosłysząca).

Większość ankietowanych ma znaczny lub głęboki ubytek słuchu, często przekraczający $100 \mathrm{~dB}$, nabyty przed 3 rokiem życia, a więc wpływający na nabywanie języka fonicznego. Wszyscy mają ponad 20 lat i zakończyli edukację szkolną.

Pierwszym językiem większości uczestników jest język polski foniczny. Ponad $50 \%$ z nich nauczyło się później języka migowego. 3 osoby z 11 przyswoiły sobie w dzieciństwie drugi język (migowy dla osoby mówiącej i polski foniczny dla osoby migającej).

Wszyscy uczestnicy uczyli się języka angielskiego, niemieckiego - 3 osoby, hiszpańskiego - 2. Przeważająca większość uczyła się tylko jednego języka - prawdopodobnie byli zwolnieni z lekcji drugiego języka przez cały czas edukacji szkolnej. Tylko dwie osoby uczyły się dwóch języków obcych, zgodnie z programem nauczania.

Dwie osoby uczyły się więcej niż dwóch języków obcych (jedna trzech, a druga czterech).

Najlepiej opanowanym językiem obcym jest język angielski, którego średni poziom wynosi B2. Z drugim językiem jest gorzej - średni poziom osób, które uczyły się więcej niż jednego języka, waha się pomiędzy A1 a A2.

Trzy osoby opanowały język angielski na poziomie C1, zaznaczając wszystkie odpowiedzi w ankiecie.

Wydaje się, że osoby niedosłyszące znacznie lepiej opanowują umiejętności czytania i pisania niż mowy i komunikacji w języku obcym, chociaż czasem najsłabszym punktem jest czytanie lub pisanie.

Czas nauki nie miał wpływu na poziom zaawansowania w skrajnym przypadku 18 lat dało tylko poziom A2. Ważne jest, że kwestionariusz CEFR nie sprawdza znajomości słownictwa czy gramatyki, a umiejętność posłużenia się językiem w ogólnych sytuacjach życiowych.
Stopień ubytku słuchu również nie rzutował na poziom i liczbę poznanych języków. Wśród ankietowanych z ubytkiem powyżej $100 \mathrm{~dB}$ mamy zarówno osobę z bardzo zaawansowanym językiem angielskim i 3 innymi językami, osobę znającą więcej niż 2 języki, ale też osoby, których poziom nie przekracza $B 1$, a czasem nawet ogranicza się do A2. Dwie osoby ze średnim ubytkiem słuchu również bardzo się różnią - jedna zna język angielski na poziomie $\mathrm{C} 1$, druga - A2.

Wyniki ankiet pokazują wyraźnie, że osoby z uszkodzonym słuchem nie stanowią jednolitej grupy, toteż nie można odmawiać im możliwości uczenia się języków obcych.

Słowa kluczowe: słabosłyszący • nauka języków obcych • poziom zaawansowania

\section{Korzyści z lektoratu języka polskiego dla osób $z$ uszkodzeniami słuchu na uniwersytecie}

\section{Renata Kołodziejczyk}

Katedra Pedagogiki Specjalnej, Katolicki Uniwersytet Lubelski, Lublin

Osoby z uszkodzeniami słuchu coraz częściej podejmują edukację na studiach wyższych. Ta przemiana w mentalności zarówno samych niesłyszących, jak i szeroko rozumianego społeczeństwa, dokonuje się pod wpływem kilku istotnych czynników: wczesnej diagnostyki, postępu w zakresie audioprotetyki, popularności kształcenia integracyjnego i ogólnodostępnego, tworzenia na uniwersytetach coraz bardziej systemowej sieci wsparcia. Pomimo tych przemian istnieje wiele obaw o to, czy młodzież z wadami słuchu poradzi sobie w różnych sytuacjach społecznych i dydaktycznych, których doświadczy na studiach, np. w zakresie rozumienia wykładów, ćwiczeń, czytanej literatury naukowej, dyskusji w grupach, a także pisania prac naukowych.

Na podstawie wywiadów ze studentami KUL z uszkodzeniami słuchu na temat trudności językowych oraz postępów w komunikacji na zajęciach $\mathrm{z}$ lektoratu języka polskiego autorka formułuje następujące wnioski:

1. Umiejętności komunikacyjne młodzieży rozpoczynającej studia są bardzo zróżnicowane - od osób, które mówią starannie, posługują się bogatym zasobem słownictwa, skomplikowanymi strukturami składniowymi, często zupełnie nie znając języka migowego, aż do osób świetnie posługujących się językiem migowym, którzy w języku polskim mówią słabo i niechętnie, a preferują komunikację za pośrednictwem tłumaczy języka migowego.

2. Każdy ze studentów $\mathrm{z}$ uszkodzonym słuchem potrzebuje pomocy i treningu w zakresie doskonalenia języka polskiego, ale każdy na nieco innym poziomie.

3. Lektorat języka polskiego ma na celu wszechstronny rozwój językowy studenta, zarówno w mowie, jak i w piśmie. Ma charakter indywidualny lub odbywa się w małych (2-3 osobowych) grupach. Program zajęć tworzony jest po zdiagnozowaniu indywidualnych potrzeb studenta. 
4. Trening językowy na lektoracie języka polskiego obejmuje umiejętności: rozumienia (np. rozumienie tekstów literackich i naukowych, rozumienie polilogu), mówienia (np. wyrazistość wymowy, operowanie prozodią mowy, wzbogacanie słownictwa, doskonalenie poprawności gramatycznej, posługiwanie się różnymi stylami wypowiedzi, wykorzystywanie frazeologii: przysłów, metafor, idiomów), pisania (np. pisanie streszczeń, notatek, parafraz, pisanie tekstów naukowych, w tym prac dyplomowych, tworzenie przypisów, bibliografii itp.).
Badania wskazują, że osoby z uszkodzeniami słuchu w okresie studiów wyższych bardzo intensywnie rozwijają swoje umiejętności językowe, dlatego organizowanie dla nich zajęć z lektoratu języka polskiego jest szansą na osiągnięcie kompetencji wystarczających do podjęcia samodzielnej aktywności społecznej i zawodowej.

Słowa kluczowe: umiejętności komunikacyjne studentów niesłyszących • lektorat języka polskiego • trening językowy • doskonalenie kompetencji 